FILOLOGIJA 74, Zagreb 2020.

UDK 811.163.42'354"19"

DOI https://dx.doi.org/10.21857/94k14czpdm

Izvorni znanstveni članak

Rukopis primljen 27. I. 2020.

Prihvaćen za tisak 22. V. 2020.

Jadranka Nemeth-Jajić

Odsjek za hrvatski jezik i književnost

Filozofski fakultet

Sveučilište u Splitu

Poljička cesta 35, HR-21000 Split

jadranka.nemeth.jajic@gmail.com

\title{
JEZIK I PRAVOPIS NOVE REVIJE - VJERI I NAUCI
}

U radu se istražuje uporabna norma hrvatskoga jezika u časopisu Nova revija - Vjeri i nauci koji je neprekidno izlazio tijekom dvaju za opstojnost hrvatskoga jezika burnih desetljeća, od 1922. do 1941. godine. Cilj istraživanja bio je steći uvid u jezičnu sliku časopisa kako bi se utvrdilo u kojoj se mjeri u Novoj reviji njeguju jezično-pravopisne značajke hrvatskoga jezika koji je u tom razdoblju bio izložen jakom utjecaju srpskoga jezika. Provedenom analizom obuhvaćeni su slovopis, pravopis, gramatika i leksik s posebnim obzirom na one jezično-pravopisne značajke koje su svojstvene hrvatskomu jeziku i koje su pokazatelji njegove posebnosti. Analiza je potvrdila početnu pretpostavku da se u Novoj reviji njeguju jezično-pravopisne značajke hrvatskoga jezika, ali je uputila i na odstupanja od hrvatske jezično-pravopisne tradicije koja su nastala pod utjecajem srpskoga jezika. Kao i u drugim onodobnim tiskovinama, taj se utjecaj ponajprije očituje na leksičkoj razini, no nije mimoišao ni pravopisnu, gramatičku ni tvorbenu razinu. Ipak, uza sva kolebanja, u promotrenim jezično-pravopisnim obilježjima Nova revija izrazitije njeguje hrvatske posebnosti, što ju svrstava u red onoga dijela novinstva koji je jezično-pravopisnim izborima u navedenome razdoblju potvrđivao hrvatsku orijentaciju.

\section{Uvod}

Nova revija - Vjeri i nauci, ugledan teološki časopis koji je izdavao Franjevački samostan u Makarskoj, izlazio je neprekidno od 1922. do 1941. godine (usp. Macut-Macut 2018). ${ }^{1}$ Vrijeme njegova izlaženja podudara

1 Usp.: »Sadržaj časopisa i međunarodna razmjena za cijelo vrijeme izlaženja svjedoče o kvaliteti časopisa i ugledu koji je uživao u teološkim krugovima« (Macut 
se s drugim razdobljem povijesti hrvatskoga standardnoga jezika u 20. stoljeću, ${ }^{2}$ koje je, kao što je poznato, za hrvatski jezik bilo vrlo teško i u kojem hrvatski standardni jezik još jednom u svojem povijesnom hodu nije imao priliku prirodno se i neometano razvijati. Jezičnim unitarizmom upravljanim iz Beograda, koji je bio izraz političkoga unitarizma, srpski je nametnut kao službeni jezik »u svim dijelovima javnog i kulturnog života (u školstvu, vojsci, sudstvu, državnoj upravi) na cijelome državnom području « Kraljevine SHS, odnosno od 1929. godine Kraljevine Jugoslavije (Samardžija 1995:107). Standardni se jezik pak kao neorganski idiom razvija i živi upravo u različitim područjima uporabe, njegova je bitna značajka višefunkcionalnost, koja je jezičnim unitarizmom dovedena u pitanje, pa je u navedenom razdoblju, kako ističe Samardžija, čak i sudbina hrvatskoga jezika bivala sve neizvjesnijom (usp. 1995:107). U takvu ozračju otpori jezičnom unitarizmu postaju još značajnijima. U jeziku javne komunikacije, kakav je jezik novina i časopisa, oni se očituju u jezično-pravopisnim izborima, u priklanjanju rješenjima koja slijede hrvatsku jezičnopravopisnu tradiciju, no ipak, kako je to bilo vrijeme izloženosti hrvatskoga jezika jakom utjecaju srpskoga, jezično-pravopisne izbore nije uvijek bilo jednostavno donositi. Načelno neprihvaćanje nametnute kodificirane norme, jer se ona u većoj ili manjoj mjeri odražavala u tekstovima onodobnih autora, bilo je značajka osobito onoga dijela javne jezične uporabe koji nije bio izravno podvrgnut državnim vlastima. Tomu dijelu pripada i katolički tisak. Ima li se na umu dugotrajnost izlaženja i brojnost čitatelja Nove revije, ${ }^{3}$ može se pretpostaviti da je to zasigurno pridonijelo učvršćivanju jezičnoga uzusa prihvaćena u tom časopisu. Držimo stoga vrijednim istražiti kakva je bila uporabna norma hrvatskoga jezika u jednom od najdugovječnijih bogoslovnih, i ne samo bogoslovnih časopisa koji su objavljivani u to vrijeme - $\mathrm{u}$ časopisu Nova revija - Vjeri i nauci.

Cilj je istraživanja steći uvid u jezičnu sliku časopisa koji će ujedno pridonijeti spoznajama dobivenima dosadašnjim istraživanjima toga nedavnog razdoblja povijesti hrvatskoga jezika. Polazišna pretpostavka jest da se u Novoj reviji njeguju jezično-pravopisne značajke hrvatskoga jezika, no kako na jezik novina i časopisa utječe izvanjezična zbilja, jednako se tako

2018:29).

2 Prema podjeli koju je predložio Marko Samardžija drugo razdoblje povijesti hrvatskoga standardnoga jezika u 20. stoljeću traje od 1918. do proljeća 1941. (usp. 1995:107). Usp. i Frančić 2013:89.

3 Usp.: »Već u prvoj godini izlaženja časopis Nova revija je postao jako poznat kod nas, a s drugim godištem ovaj časopis prelazi naše granice i ulazi u široki krug ondašnje svjetske javnosti. Čitala se u Francuskoj, Njemačkoj, Belgiji, Austriji, Švicarskoj, Čehoslovačkoj i Turskoj« (Fra Ante Cikojević. Izabrani spisi 2008:24). 
očekuju i odstupanja od hrvatske jezično-pravopisne tradicije. Analizom su stoga obuhvaćeni slovopis, pravopis, gramatika i leksik s posebnim obzirom na one jezično-pravopisne značajke koje su svojstvene hrvatskomu jeziku i koje su pokazatelji njegove posebnosti. S obzirom na opseg rada analizom nisu mogla biti obuhvaćena sva takva obilježja, pa je to ujedno i ograničenje provedenoga istraživanja.

U analizi posebice uzimamo u obzir dvije opsežne studije zbog toga što one pružaju mogućnost usporedbe Nove revije s drugim onodobnim tiskovinama. To su Jezik hrvatskih novina i časopisa u 20. stoljeću Vlaste Rišner i Jadranke Mlikota (2018:245-301) i Jezik i pravopis splitskoga novinstva između dvaju svjetskih ratova Anđele Milinović (2014). Naznačujući glavne tokove u jeziku hrvatskoga novinstva u 20. stoljeću, prva studija pruža uporište za sagledavanje mjesta i uloge Nove revije u vremenu kojem je pripadala. Podrobna analiza Novoj reviji vremenski podudarnih unitarnih i oporbenih, radićevski naklonjenih glasila, provedena u drugoj studiji, omogućuje pak usporedbu s uporabnom normom onih splitskih dnevnika koji su također nastojali provoditi hrvatsku jezičnu politiku.

U jezično-pravopisnoj analizi časopisa Nova revija služimo se nazivom Broz-Boranićeva norma (usp. Badurina 2018:157). Pod tim nazivom razumijevamo pravopisnu normu utvrđenu Hrvatskim pravopisom Ivana Broza, objavljenim u dvama izdanjima, 1892. i 1893. godine, te neznatno izmijenjenim njegovim inačicama: pravopisom naslovljenim Dra. Ivana Broza Hrvatski pravopis koji je nakon Brozove smrti priređivao Dragutin Boranić, a koji je imao četiri izdanja, 1904., 1906., 1911. i 1915. godine, potom četirima samostalnim izdanjima Pravopisa hrvatskoga ili srpskoga jezika Dragutina Boranića, objavljivanima od 1921. do 1928. godine. Prekid s BrozBoranićevom normom donosi peto izdanje Boranićeva pravopisa objavljeno 1930. godine jer je ono prerađeno prema službenom i obvezujućem Pravopisnom uputstou za sve osnovne, srednje i stručne škole Kraljevine S. H. S. iz 1929. godine koje je, provodeći jezičnu politiku ujednačivanja hrvatske i srpske pravopisne norme, uglavnom prihvatilo pravopisna rješenja izložena u Pravopisu srpskohrvatskog književnog jezika Aleksandra Belića. Boranićev takozvani »dogovorni pravopis « iz 1930. imao je još dva izdanja, šesto iz 1934. i sedmo iz 1937., naslovljena Pravopis hrvatskosrpskoga jezika. Tako od tridesetih godina »u hrvatskoj pisanoj praksi«, navodi Samardžija, »postoje tri pravopisa, dva neslužbena: tradicionalni, pretežito morfonološki (etimološki, korijenski) kojim su objavljivane publikacije pravaša i HSS-a te drugih izdavača i Boranićev fonološki te službeni >dogovorni< također fonološki« (Samardžija 2018:27). Osnutkom Banovine Hrvatske uki- 
da se »dogovorni pravopis« te se Naredbom o pravopisu ${ }^{4}$ od 1. rujna 1940. naređuje »da se na području banovine Hrvatske $\mathrm{u}$ banovinskim uredima, zavodima i školama javim i privatnim upotrebljava pravopis, koji je bio u upotrebi do 1929. godine " (Naredba o pravopisu u Samardžija 2018:34), to jest u uporabu se vraća » >kanonska< inačica Boranićeva pravopisa čije je ponovljeno 4. izdanje objavljeno već 1939., a 8 ., tzv. banovinsko u početku god. 1941.« (Samardžija 2018:32).

\section{Kratak opis časopisa}

Pokretač je časopisa, ujedno prvi glavni i odgovorni njegov urednik, bio dr. fra Petar Grabić, a uređivao ga je do 1931., kada uredništvo preuzimaju profesori franjevačkog bogoslovlja u Makarskoj. Godine 1934. urednikom je imenovan dr. fra Božo Vuco (Vucić), koji tu dužnost obavlja do kraja izlaženja časopisa 1941. godine (usp. Macut-Macut 2018). Do godine 1933. izdavana su četiri broja godišnje, poslije šest brojeva, s tim da su pojedini brojevi izlazili kao dvobroj. U posljednjoj godini izlaženja zbog ratnih neprilika, nakon prvoga broja, brojevi od 2 do 6 izašli su u jednome svesku. ${ }^{5}$ Časopis je objavljivao izvorne teološke i filozofske radove, članke iz drugih područja kao što su povijest i bliske znanosti, recenzije aktualnih teoloških i filozofskih knjiga, a obrađivala su se i relevantna kulturna, pedagoška i vjerska pitanja (usp. Macut 2018:29-30). »Nova revija je«, navodi Glibota, "pratila čitav kulturni život, a sve njegove pojave promatrala je pod vidom katoličkih načela, moralnih istina i nacionalnih ideala, pa je postala kulturna potreba za naš katolički intelektualni svijet, kao svjetlo i pomoć u vrtlogu novih strujanja i pokreta. Njezini suradnici«, obavješćuje isti autor, »bila su prvoklasna pera, koja su služila katoličkoj istini, branili nauk svete vjere« (Fra Ante Cikojević. Izabrani spisi 2008:24). Časopis je imao stalne rubrike. Na početku su se nalazili teološki i filozofski radovi, potom su slijedile rubrike naslovljene Kulturni pogledi, Književni pregled ${ }^{6}$

4 Naredba o pravopisu, br. 65.842-II-1940., Službeni glasnik banske vlasti Banovine Hrvatske Odjela za prosvjetu, str. 575-576, Zagreb, 1940. Izvor: Samardžija 2018:34.

5 Obraćajući se svojim pretplatnicima, Uredništvo o tome kaže: »Poslije nego smo izdali prvi broj Nove Revije za god. 1941. u svijetu oko nas nastale su poznate promjene i prilike, u kojima smo morali počekati sa daljnim izdavanjem našega časopisa. Mislili samo da ćemo do konca godine 1941. ipak izdati još bar koji broj. Međutim prilike su bile jače i do konca godine izišao je samo prvi broj. Mi samo ipak odlučili da ne prestanemo s daljnim izdavanjem, te da popunimo godinu 1941., izdajemo zaostale brojeve (2-6) u ovom svesku. U današnjim neobičnim prilikama naši će nas pretplatnici razumjeti i uvažiti, pošto nas je i ovaj posao stao mnogo truda i nastojanja « (Nova revija, 1941., 2-6, posljednja stranica, nepaginirano).

6 Umjesto naziva Književni pregled u pojedinim brojevima nalaze se nazivi Knji- 
i Vjesnik, a od prvoga broja 1923. i kronika, koja je do 1934. izlazila redovito: na francuskom pod naslovom Chronique religieuse en Yougoslavie (do 1929.) i na latinskom jeziku pod naslovom Chronica (od broja 3-4 1929. do broja 2 1934.), te povremeno u sljedećim godištima na francuskom jeziku. Za uredništva Bože Vuce Vjesnik je u nekim brojevima imao dvije podrubrike, Iz naših krajeva i Iz stranog svijeta. Nova rubrika Iz narodne starine, u kojoj se donose i komentiraju uglavnom povijesni i crkvenopravni arhivski spisi, uvodi se od dvobroja 3-4 iz 1927., a zadržana je do prvoga broja 1929. godine.

U prvome desetljeću izlaženja časopisa gotovo se u svakome broju nalazio po jedan teološki rad objavljen u izvorniku na slovenskom jeziku. Sažetci uvodnih članaka pišu se uglavnom na francuskome, gdjegdje i na latinskom jeziku. Arhivski su prilozi u rubrici Iz narodne starine navedeni u izvorniku, na hrvatskome, ${ }^{7}$ latinskom i talijanskom jeziku. Citati se u svim tekstovima donose na izvornome jeziku, uglavnom na latinskome i srpskome. Citati na hrvatskome jeziku također se navode vjerno izvorniku. Naslovi knjiga i bibliografski podatci u rubrici Knjižeoni pregled navode se izvorno pa su naslovi onih knjiga koje su objavljene na ćirilici tako i napisani. U pojedinim brojevima priložen je popis knjiga što ih je zaprimilo uredništvo, pri čem su imena autora, naslovi knjiga i bibliografski podatci također izvorno navedeni.

\section{Jezična analiza}

Analizirani su samo tekstovi na tada suvremenome hrvatskome jeziku. $\mathrm{U}$ analizu se nastojao uključiti reprezentativni korpus tako da su birana godišta koja pokrivaju cijeli vremenski raspon izlaženja časopisa: ona na početku njegova izlaženja, potom potkraj dvadesetih i na početku tridesetih godina te ona potkraj tridesetih do kraja izlaženja časopisa, dok su brojevi časopisa koji su podvrgnuti analizi birani nasumice. Uz preuzete primjere iz uporabne norme u zagradama je navedena godina izlaska časopisa, broj sveska i broj stranice.

\section{Slovopis}

Od početka izlaženja u Novoj se reviji bilježi grafem d: rađati, Petrovu lađu (1922., 1: 2), događalo (1922., 1: 18), evanđeljima (1922., 1: 35), rođenog, gradi (1923., 1: 2), a vrlo se rijetko nailazi na dvoslov dj: subdjakonat (1922., 1: 24), imadjahu (1922., 1: 79), izvadjale (1922., 2: 189), djaci (1929., 1: 62). To

žeonost i Knjižeuni pogledi.

7 Tekstovi pisani bosančicom preneseni su latinicom. 
pomalo začuđuje ima li se $u$ vidu nesklonost tadašnjega tiska uvođenju slova đ. Ono se uglavnom uvodi krajem drugoga i početkom trećega desetljeća 20. stoljeća, no često se u istim novinama usporedo rabe i dvoslovi dj i gj, koji su se kao dio slovopisne hrvatske tradicije zadržali sve do polovice 20. stoljeća (usp. Rišner-Mlikota 2918:249; Milinović 2014:73-76). Rišner i Mlikota navode međutim da Crvena Hrvatska ${ }^{8}$ već 1906. uvodi slovo d, što tada predstavlja iznimku, a razlog tomu vide u slovopisnom nastavljanju dubrovačke tradicije. Dubrovački pravaški list zasigurno je bio poznat uredništvu Nove revije, koja se u početku i tiskala u Dubrovniku, što bi moglo objasniti nezaziranje od uvođenja grafema $d$.

\section{Pravopis}

Pisanja velikoga početnoga slova samo ćemo se uzgred dotaknuti napomenom da su se $u$ onodobnim novinama svi članovi naziva novina redovito pisali velikim početnim slovom bez obzira na to jesu li ili nisu vlastito ime, pa je tako na naslovnici svih brojeva pisalo Nova Revija. Nije to bilo u skladu s Broz-Boranićevom normom koja je u višečlanim nazivima veliko početno slovo propisivala samo na početku naziva i samo za one članove naziva koji su i sami vlastito ime. Pisanje svih članova naziva velikim slovom, osim veznika i prijedloga, propisuje pak Belićev pravopis, dok se Pravopisno uputstvo u tome priklanja Broz-Boranićevu pravilu. Praksu pisanja svih članova naziva novina velikim početnim slovom Milinović tumači uglédanjem na srpske novine (usp. Milinović 2014:81), no mogla bi se ona povezati i s privlačenjem pozornosti čitatelja kao značajkom novinsko-publicističkoga stila. Naime, i suvremeni pravopis Babića, Finke i Moguša iznimno dopušta pisanje svih riječi u naslovima velikim početnim slovom u osobitim namjenama pisane riječi, iz estetskih, reklamnih, propagandnih i drugih razloga (usp. Babić-Finka-Moguš 1994:23).

U pogledu pravila koja razrješuju odnos pisanja prema izgovoru, to jest primjene fonološkoga ili morfonološkoga načela, Nova revija u osnovi prihvaća Brozov fonološki pravopis (1892.) i kasnija neznatno izmijenjena izdanja koja je do 1915. priređivao Dragutin Boranić (Broz-Boranićeva norma). Ipak se, češće u prvim godištima, morfonološko pisanje zadržava uglavnom pri neprovođenju jednačenja glasova po zvučnosti u riječima latinskoga podrijetla: absurd (1922., 1: 3), absolutno pravo, absorbirala (1922., 1: 10), absorbira (1928., 2: 127), absolutne (1939., 4: 288), obskurantizam (1924., 2: 180) te na granici predmetka i korijena riječi:predpostavi (1922., 1:3), bezkonfensionalce (1922., 1: 6), I politika je raztrovana. (1923., 1: 5), raztrovaše (1923., 1: 8) iako, pa i u istim brojevima časopisa, ima i provedenoga jedna-

\footnotetext{
8 Crvena je Hrvatska izlazila od 1891. do 1914. godine.
} 
čenja: pretkršćansko doba (1923., 1: 2), rastrojstvo (1923., 1: 5), otpočine, isključivu (1923., 1: 7), prethodne (1924., 2: 157), nenatkriljiv (1924., 2: 158), istjera (1924., 2: 167), pretpostavljati, apsolutnu (1924., 2: 170), beskarakterne (1924., 2: 173), apsurdno (1924., 2: 190), pretplatnika (1924., 2: 208), koje u kasnijim godištima prevladava. Morfonološki način pisanja rijetko se potvrđuje na granici korijena riječi i dometka: učbenika (1938., 3: 231), ali i udžbenika (1922., 1: 4), no zadržava se u osobnim imenima: Tvrdkovom vojskom, Tordko (1941., 5-6: 56). Gdjegdje se, također češće u prvim godištima, nailazi na primjere neprovedenoga jednačenja glasova po izgovornome mjestu: najedanput (1922., 1: 60), ${ }^{9}$ činbenike (1923., 1: 5), isčeznuše (1923., 1: 8), českih kruna (1930., 3: 237), Česke (1930., 3: 248), stanbena (1939., 5-6: 469) iako se ono u skupinama šumnika uglavnom provodi: dršće (1924., 2: 127), iščupaju (1924., 2: 149), iščezava (1924., 2: 182), češki biskup (1932., 2: 190), ǐčchureni (1938., 3: 208). Zanimljivo je promotriti tri načina bilježenja prezimena Matije Gupca u tekstu istoga autora: Gupca, Gubcu, Gobec (1938., 3: 208209), koji zrcale hrvatske pravopisne osebujnosti. Autor teksta prezime bilježi s provedenim jednačenjem po zvučnosti, Gupca, pri spominjanju pjesme Mihovila Pavleka Miškine ostavlja izvorni naslov Matiji Gubcu, a pri citiranju povjesničara Ferde Šišića izvorni kajkavski oblik Gobec. Neprovedeno jednačenje glasova po zvučnosti i izgovornome mjestu zabilježeno je u primjeru sv. Frani Asizkomu (1923., 1: 17), dok su oba jednačenja provedena u svečanom broju posvećenu tomu svetcu: O sv. Franji Asiškomu kad se navršuje 700. godišnjica od njegove smrti (1926., 3-4: 203). Iz navedenih je primjera razvidno da se prihvaćanje fonološkoga načina pisanja odvijalo postupno i ne bez kolebanja.

U pisanju suglasničkih skupina $d c, d \check{c}, d c ́, d s, d \check{s}$ uglavnom se poštuje Broz-Boranićeva norma, pa zvučni $d$ ne prelazi u $t$ kako je bilo propisano Belićevim pravopisom: trećoredskog jubileja (1922., 2: 188), sredstvo (1924., 2: 128), nadčovječan (1924., 2: 173), Odsjev (1932., 1: 3), ljudska (1932., 1:4), podsvijesti (1939., 5-6: 477), odskaču (1941., 5-6: 76), ali se, osobito tridesetih godina, nailazi i na primjere s provedenim jednačenjem: ljutski (1928., 2: 137), potsjetiti (1929., 1: 40), otsijev (1938., 3: 193), pretstaviti, otcijepljenim (1938., 3: 196), potcjenjuju (1938., 3: 214), otsjeka (1938., 3: 220), pretsjedniku (1939., 5-6: 494), potcrtavam (1941., 1: 1). U oblicima imenica koje završavaju na -dac, -dak, -tac, -tak gubljenje suglasnika $d$ i $t$ pretežito se provodi: napuci (1923., 1: 9), probicima (1924., 2: 121), podaci (1924., 2: 190; 1929., 1: 24; 1940., 3-4: 333), Sveci (1930., 3: 233), crkvenim ocima (1930., 3: 241), dodaci

9 Pri jednačenju suglasnika $n$ ispred $b$ i $p$ Broz-Boranićeva norma nije pravila razliku između izvedenica i složenica te je propisivala bilježenje govorne promjene: jedamput, čimbenike, stambena. 
(1930., 3: 248), u zadnjim recima (1930., 3: 249), podacima (1938., 3: 219), nadodacima (1938., 3: 233), o počecima (1938., 3: 233), izvacima (1938., 3: 235), ostaci (1941., 5-6: 27), uz tek pokoji usporedni način bilježenja: retcima (1922., 1: 90), domorodcu (1922., 1: 93), želudcu (1922., 2: 183), Samostanski Trećoredci (1922., 2: 187), u Mletcima (1924., 2: 206), izvatcima (1938., 3: 238). Nailazi se i na oba načina bilježenja u tekstu istoga autora: Mletcima, Mlecima (1922., 1: 79). S obzirom na to da se, u skladu s Brozovim pravopisom, u onodobnim oporbenim splitskim dnevnicima češće čuva pisanje razlikovnih suglasničkih skupina $d c$, $d \check{c}$ i $t c$, tč (usp. Milinović 2014:146), očekivalo bi se da se tako čini i u Novoj reviji.

U pisanju dvoglasnika ie u pokraćenim slogovima iza pokrivenoga $r$ tijekom obaju desetljeća izlaženja časopisa zamjećuju se dvostrukosti, re/rje, pa i pisanje rije: pogrešno (1922., 1: 14), bez povrede (1922., 1: 58), zapreka (1922., 1: 44; 1924., 2: 116; 1941., 5-6: 26), zaprijeke (1922., 1: 82), zadovoljštinu za uvrijede (1922., 1: 96), griješna (1922., 2: 146), vrednotama (1923., 1: 4), kreposti (1923., 1: 7; 1924., 2: 125), pogrešaka (1924., 2: 118), u krjeposti (1924., 2: 180; 1929., 1: 110), Trijezniji (1924., 2: 154), uvrjeda (1927., 3-4: 255), pogrješke (1927., 1: 36), Bezgrješne Djevice (1929., 1: 9), pogrješka (1929., 1: 37), grješno (1929., 1: 11), o papinskoj nepogrješivosti (1929., 1: 12), pogreške (1929., 1: 19), pogrješku (1930., 3: 233), grešnike (1930., 3: 248; 1938., 3: 162), grješnika (1938., 3: 187), najurijednije (1938., 3: 236), okrepa (1939., 5-6: 467; 1941., 5-6: 86), grješka (1940., 3-4: 316), najurjedniji dio (1940., 3-4: 333), najurijednija i najbolja djela (1941., 5-6: 76), u kapelici Bezgrješne (1941., 5-6: 27), grješnici (1941., 5-6: 34), kreposnih muževa (1941., 5-6: 37), vrednotu (1941., 5-6: 73). Osim u riječi grješka i njezinim tvorenicama, izostavljanje fonema $j$ iza pokrivenoga $r$ postupno je prevladalo. No unatoč tomu što su Boranićevim pravopisom iz 1921. bili dopušteni samo oblici s e, oblici s rje nisu se prestali povezivati s čuvanjem značajka hrvatskoga jezika, pa su, makar i u manjem broju, opstali u onodobnom hrvatski orijentiranom tisku. ${ }^{10}$ Dvostrukost ije/e zamjećuje se u primjerima prijegled (1924., 2: 201), pregled (1924., 2: 202), prevoda (1922., 1: 79), Prijevod (1927., 3-4: 342), no u dugim slogovima češće se biraju oblici s ije: prijevare (1922., 2: 182), samoprijegora (1923., 1: 93; 1933., 1-2: 69), prijekora (1938., 3: 221), prijedlog (1940., 2: 173), prijedloga (1940., 2: 175). Zanimljivo je promotriti imenice starješina i starješinstvo, koje se do potkraj dvadesetih godina uglavnom bilježe u jekavskom obliku, no nadalje ih se zatječe i ekavizirane: starješina franjevaca (1922., 1: 92), starješinama (1922., 2: 146), starješine (1922., 2: 183; 1927: 3-4: 325), franje-

10 Npr. u Hrvatskom listu (usp. Rišner-Mlikota 2018:256). Milinović također navodi: »Oblici s pokrivenim /r/, iako malobrojni, ipak su se zadržali u praksi splitskih, većinom oporbenih dnevnika« (Milinović 2014:131). 
vačkih starješinstava (1922., 2: 187), starješinstva (1922., 3: 286), starješinstvo (1923., 4: 396; 1925., 3: 323; 1926., 3-4: 530; 1927., 3-4: 370; 1928., 3: 329), starešine (1933., 1-2: 70), starešinstvo (1925., 4: 437; 1928., 1: 105; 1928., 4: 434; 1934., 6: 473; 1940., 3-4: 319). Niječni oblik prezenta glagola biti u standardnojezičnom obliku nisam, nisi... javlja se tek iznimno: nisu (1922., 2: 101), nismo (1940., 3-4: 325), Nisu (1940., 2: 98). Prevladava jekavski oblik karakterističan za dubrovačke govore, ali i za književni jezik štokavskoga Dubrovnika: nijesam (1922., 2: prilog, nepaginirano), Nijesam (1933., 1-2: 73), nijesi (1938., 3: 212; 1941., 5-6: 27), nijesmo (1924., 3: 309; 1928., 2: 145), nijesu (1922., 1: 4, 91; 1922., 2: 160, 162; 1924., 2: 116, 156; 1928., 2: 120; 1933., 1-2: 73; 1940., 3-4: 316), što Novu reviju povezuje s dubrovačkim odvjetkom hrvatske književnosti.

U pisanju riječi iz drugih jezika hrvatska se i srpska pravopisna norma razlikuju: izvorno pisanje posuđenih općih imenica i stranih vlastitih imena propisuje Broz-Boranićeva norma, osim za izgovorno prilagođene riječi iz latinskoga i grčkog jezika te neke tada već uobičajene riječi; fonetsko pisanje, prema izgovoru, propisuje Belićeva pravopisna norma, Pravopisno uputstvo i izdanja Boranićeva pravopisa tridesetih godina koja su usklađena s Uputstvom. Nova revija slijedi Broz-Boranićevu normu: riječi koje su se tada još osjećale kao tuđice te tuđa vlastita imena i njihove izvedenice, osim onih odavno prilagođenih, pišu se izvorno: Gentleman (1924., 2: 133), münchenskoga profesora (1924., 2: 199), izmjenu (amendement) (1924., 2: 152), Bassin (1925., 3: 326), motto (1938., 3: 227), budgetska godina (1940., 3-4: 316), uz određena kolebanja pri pisanju imena New Yorka i njegovih izvedenica: New York, ali i Newyork (1933., 1-2: 74), New-York (1939., 5-6: 475); newjorškog nadbiskupa (1933., 1-2: 75), New-Yorških škola (1924., 2: 206), newyorških liječnika (1939., 5-6: 472). Pisanje tuđih vlastitih imena prema izgovoru rijetko je zamijećeno: nad padom Habzburgovića (1930., 3: 226), Martin Luter, dvorkinjom Anom Bulenom (1938., 3: 206). Kolebanja se međutim javljaju pri umetanju spojnice između osnove i nastavka, pa se često, i u istome tekstu, nalaze primjeri napisani sa spojnicom i bez nje: milieu-a (1922., 1: 2), Clemencau-a, Poincaré-a, Wilsona (1924., 2: 122), Dhorme-ov, Gressmann-a, Scheil-ov, Gressmannov (1929., 1: 18), Buchbergera, Hofmanna (1930., 3: 228), u Liège-u (1930., 3: 242), kard. Pacelli-a, Pacelli-u (1938., 5: 372), Dausenda (1939., 5-6: 495), Georges Goyau-a (1939., 5-6: 498), u New-Orleans-u (1940., 3-4: 344). Ta pravopisna nesigurnost može biti posljedica još nedostatno učvršćene norme. Boranić je naime u svojem pravopisu iz 1921. uveo Belićevo pravilo da se pri sklonidbi osnova i nastavak odvajaju spojnicom, dok se u dotadašnjim izdanjima Brozova i Broz-Boranićeva pravopisa pravila o sklonidbi posudenica i stranih vlastitih imena ne navode. Kako je takvih ko- 
lebanja pri pisanju stranih prezimena bilo i u hrvatskim novinama i časopisima potkraj 19. stoljeća (usp. Rišner 2015:273), ona bi se također mogla protumačiti kao nasljedovanje neujednačene novinske prakse.

U prilagodbi posuđenica neujednačeno se bilježi fonem $j \mathrm{u}$ hijatskom položaju između dvaju otvornika: lekcijonar (1922., 1: 79), socijolozi (1922., 2: 145), sociologiju (1924., 2: 176), konfesijonalne škole (1924., 2: 190), Konfesionalne škole (1940., 2: 159), religijoznim su se pitanjem (1922., 1: 7); religiozno odgoje (1922., 1: 8), nacionalizirati (1922., 1: 47), Nacijonalizam (1923., 1: 89), nacionalizam (1940., 2: 106), nacijonalni (1927., 1: 25), nacionalnu (1927., 1: 35), internacijonala (1923., 1: 93), internacionalan (1940., 2: 108), religiozni život, religijoznoga života (1929., 1: 40), misijonari (1924., 2: 203), misionari (1930., 3: 244), miliona (1922., 1: 69), milijona (1924., 2: 207), ${ }^{11}$ reakcijonarnog fašizma (1928., 2: 130), materialnu pomoć, materialnim sredstvima (1922., 1: 70), materijalni objekt (1922., 2: 192), materialisti (1928., 2: 130), hierarhije (1924., 2: 152), hierarhično (1924., 2: 163), hijerarhija (1924., 2: 189), laičke (1922., 1: 6), lajičke (1941., 5-6: 19). Takva su kolebanja zapažena i u drugim hrvatskim tiskovinama prve polovice 20. stoljeća (usp. Rišner-Mlikota 2018:258-260), pa i ona mogu biti posljedicom nedovoljno jasne norme s obzirom na to što »Boranić u četvrtom izdanju Brozova pravopisa spominje tek neke od mogućnosti umetanja hijatskoga $j$ ili izuzetaka od umetanja« (Rišner-Mlikota 2018:258).

Posuđenice autor, autoritet i njihove izvedenice pišu se prema izgovoru u latinskom jeziku iz kojega su preuzete (lat. auctor, auctoritas): auktor (1922., 1: 82; 1922., 2: 174; 1940., 3-4: 337), auktoritetom (1924., 2: 174), auktoriteta (1929., 1: 6; 1941., 5-6: 73), auktoritativan (1929., 1: 31), auktoritativnomu (1938., 3: 160). Imena Mađar, Mađarska i njihove izvedenice, kao i u drugim tadašnjim tiskovinama, ${ }^{12}$ bilježe se dvojako, češće sa $d$, prema izvornome izgovoru, rjeđe sa $d \check{z}$, pod utjecajem izgovora u turskom jeziku (usp. Babić-Finka-Moguš 1994:66): Mađari (1923., 1: 90), Mađarskoj (1923., 3: 308), Mađarska (1933., 4: 312; 1937., 1: 78; 1937., 2: 168; 1937., 3-4: 294; 1939., 2: 157; 1940., 1: 95), Madžarskoj (1924., 3: 304), Madžarska (1934., 3-4: 318; 1934., 5: 398; 1934., 6: 476). Posuđenica šport/sport s obzirom na tematiku časopisa nije česta, no prevladava oblik koji se povezuje s hrvatskom tradicijom: šport (1927., 3-4: 282), športa, šport (1928., 2: 131), sporta (1940., 2: 98), športska i zabavna udruženja (1924., 2: 150), športske igre (1929.,

11 Ta se riječ javlja i u suvremenom normom propisanu obliku: milijuni (1922., 2: 98), milijuna (1939., 5-6: 494).

12 Kako se u Novoj reviji od samog početka izlaženja bilježio grafem $d$, tako se ne nalaze pojavnice Magjarska i Madjarska, koje su se javljale u tadašnjim novinama i časopisima. 
1: 62). Nasuprot tomu Europa i njezine izvedenice češće se bilježe $\mathrm{s} e v$, što je, priklanjajući se Karadžić-Daničićevu rješenju, propisivao Maretić (usp. 1931:62): Evropom (1923., 1: 98), Evropljanine (1923., 1: 90), Europi (1924., 2: 202), Evropu (1929., 1: 4); evropskim državama (1929., 1: 7), evropejac, Evropljani, Evropljanina (1938., 5: 376), Europe (1938., 3: 149, 195), Evropa (1940., 2: 106), poevropiti Rusiju (1940., 2: 111), evropskog čovjeka (1941., 5-6: 73) iako bi se očekivalo da pretežu oblici s eu, kako je to bilo u splitskim oporbenim dnevnicima (usp. Milinović 2014:101). Utjecaj srpskoga jezika u prilagodbi posuđenica, osobito nakon 1929. godine, očituje se i u inačicama riječi kakve su Jerusalemu (1929., 1: 95), Persiji (1929., 1: 9), persijanski (1929., 1: 39), Israela (1929., 1: 24), resumira (1929., 1: 89), konsorcij (1935. 1: 82), balsam (1938., 3: 235). Posuđenica aktualan, prilagođena u skladu s hrvatskom normom prema latinskome jeziku, zatječe se i u liku aktuelan, prilagođenu prema francuskome, a što je uvriježeno u srpskom jeziku: aktualna pitanja (1924., 2: 206), aktuelnu temu (1941., 5-6: 77). Uz hrvatski lik riječi barbarstvo zabilježena je i srpska inačica: $k$ varvarstvu vraća (1923., 1: 6), varvarstvo na jugu (1929., 1: 5).

U skladu s Broz-Boranićevom normom zanijekani se oblik prezenta glagola htjeti piše rastavljeno: ne će (1923., 1: 3; 1924., 2: 114, 173; 1929., 1: 6, 37; 1930., 1: 5; 1938., 3: 205; 1939., 5-6: 466; 1940., 2: 159), ne ćete (1929., 1: 38), ne ćeš $(1929 ., 1,39)$, no nailazi se i na pokoji primjer sastavljenoga pisanja: neće (1922., 1: 3; 1938., 3: 185, 194; 1940., 3-4: 219), Nećemo (1940., 3-4: 325). U oblicima futura I. također se pretežito poštuje hrvatska pravopisna tradicija pa se $\mathrm{u}$ infinitivu glagola na - $t i$, kad se zanaglasnica nađe iza infinitiva, gubi završno $i$ : uvidjet će se (1922., 1: 8), Nastavit će se (1923., 1: 29; 1928., 1: 12), Završit će se (1927., 1: 21), nastavit će se (1940., 2: 153), dovest će (1924., 2: 171), uspostavit će, odvratit će (1929., 1: 6), promotrit ćemo (1929., 1:9), no i tu su zamijećeni primjeri sastavljenoga pisanja propisanoga Belićevim pravopisom: Nastaviće se (1922., 1: 10, 64) i Pravopisnim uputstvom: činiću, staviće, pitaće se, dogodiće nam se (1938., 3: 220), a gdjegdje i primjeri s punim infinitivnim nastavkom: imati će, isplutati će (1922., 1: 3), gledati će (1929., 1: 40), prevesti ću (1938., 5: 336), vidjeti ćemo (1939., 5-6: 468).

U pisanju zareza Nova revija slijedi Broz-Boranićevu normu temeljenu na strukturnoj (gramatičkoj) interpunkciji po kojoj se "pisanje interpunkcijskih - u pravom smislu rečeničnih - znakova propisuje s obzirom na rečeničnu strukturu « (Badurina 2018:179), to jest zarezom se odvajaju surečenice zavisno i nezavisno složenih rečenica te umetnute rečenice. Primjeri: Cijena revije makar se kome činila velika, uzevši u obzir tiskarske prilike, nije mogla da bude manja. Preporučamo se uglednim dobročincima, da nas potpomognu i milodarima. (...) Ako Gospoda ne vide objelodanjene svoje radove u ovom 
broju, izaći će, kad stignu na red. (1922., 1: početna stranica, nepaginirano); One svete misli, koje se dižu s njezinih usta, jesu sveta pjesma, a sveta pjesma jesu one svete misli. (1924., 2: 130); Činjenica je, s kojom treba ipak računati, da je Kantov utjecaj na noviju filozofiju nedvojben. (1924., 2: 176); Bog je uzeo čovječje tijelo, da čovjek može uzeti Božjeg duha. (1940., 2: 98); Koliko god izgledalo na proi mah da je čovjek profinjena materija, pače iako kadikada vidimo u njemu nagonske i slijepe životinjske sile, ipak, nakon malo zrelog mišljenja, vidimo, da je duh najintimnija čovječja narav. (1940., 2: 173). Poštivanjem strukturne interpunkcije izbjegnute su nedosljednosti u pisanju zareza koje su u tadašnjoj novinskoj praksi nastajale nakon što je Boranićevim pravopisom usklađenim s Pravopisnim uputstvom uvedena Belićeva logičko-semantička ili slobodna interpunkcija (usp. Rišner-Mlikota 2018:253).

Na kraju naslova i podnaslova redovito se stavlja točka i time poštuje Brozovo pravilo koje to propisuje, za razliku od novinskih naslova onodobnih splitskih dnevnika u kojima se točka ne bilježi (usp. Milinović 2014:113).

\section{Gramatika}

U Novoj reviji, kao i u drugim novinama i časopisima u promatranome razdoblju, pojedine imenice poprimaju gramatička obilježja različita od onih koja imaju u suvremenome hrvatskom jeziku. Tako se u nominativu jednine imenica muškoga roda, iz težnje da se prilagode fonološkom sustavu hrvatskoga jezika, između dvaju završnih suglasnika često umeće nepostojano a: elemenat (1924., 2: 133), protestanat (1924., 2: 153) projekat (1924., 2: 190), argumenat (1928., 2: 130), parlamenat (1928., 2: 178), Sakramenat (1933., 1-2: 74), sakramenat (1940., 2: 105), efekat (1938., 3: 160), akcenat (1938., 3: 226), no potvrđuju se i oblici bez nepostojanog a: objekt (1922., 2: 192; 1928., 2: 128), projekt (1928., 2: 178), protestant (1928., 2: 178) patent (1928., 2: 183). Utjecaj srpskoga jezika očituje se pak u imenica muškoga roda koje u suvremenome hrvatskom jeziku u nominativu jednine imaju suglasnički završetak i nulti nastavak, a u onodobnim tiskovinama često imaju nastavak $a$ i sklanjaju se prema $e$-sklonidbi. U Novoj reviji takve se imenice nalaze podjednako i $\mathrm{u}$ jednome i u drugom obliku, pa i u tekstu istoga autora: slavist (1922., 1: 72), fantast (1924., 2: 117), koji je altruista (1924., 2: 118), telepatisti (1924., 2: 183), racionalist (1924., 2: 187; 1939., 5-6: 499), panteist, ekstremist (1929., 1: 30), nihilist (1929., 1: 31), kaže mu se da je indiferentista (1929., 1: 46), indiferentisti (1929., 1: 47), liberalni protagoniste, drugi su panteiste, spiritualisti, materijalisti (1929., 1: 60), ateist (1930., 3: 204), metropolite Dionizija, metropolit Dionizije (1930., 3: 244), pesimist (1938., 3: 151), da su tu ulogu vršili donatiste u stara vremena (...), pa anabaptiste (...), 
janseniste (1938., 3: 196), Enciklopedisti (...), i svi ostali cezaropapiste! (1938., 3: 205), kapitaliste Marksa (1938., 3: 209), moralist, kanonist, pastoralist, liturgisti (1938., 3: 231). S druge strane, utjecaj srpskoga jezika na rod imenica u Novoj je reviji bio nešto manje izražen nego u drugim tadašnjim novinama i časopisima. Imenica osnova, primjerice, zamijećena je samo u ženskome rodu: u naukovnu osnovu (1922., 1: 5), na novoj osnovi (1924., 2: 160), zajedničku osnovu (1929., 1: 24), Božjih osnova (1938., 3: 186), a teritorij u muškome rodu: na teritoriju (1930., 3: 244), što su oblici tipični za hrvatski jezik, za razliku od onodobnih splitskih novina u kojima su zamijećeni i oblici osnov i teritorija, tipični za srpski jezik (usp. Milinović 2014:148-149). No imenice kvaliteta i kvantiteta potvrđene su u muškome rodu: ovi njegovi kvaliteti (1930., 3: 238), kvalitet, kvantitet (1940., 2: 106). Imenica konklava, koja se u splitskim novinama bilježi u muškome rodu (usp. Milinović 2014:149), u Novoj reviji, kao i u suvremenome jeziku, ženskoga je roda: Papine konklave, koje su potrajale (1940., 2: 113). Imenica vrsta u danas zastarjelu obliku vrst, koja se sklanja po $i$-sklonidbi, zadržava se duže negoli u drugim onodobnim novinama u kojima se rabi do dvadesetih godina (usp. Rišner-Mlikota 2018:261): svake vrsti (1923., 1: 2), jedna vrst (1923., 1: 17), no kasnije i u Novoj reviji prevladava oblik vrsta koji se sklanja po e-sklonidbi: neka vrsta (1928., 1: 26), Vrste novih škola (1929., 1: 61).

U skladu s normom zagrebačke filološke škole u genitivu množine imenica pretežito se javlja nastavak $-a$, a ne $-i$, koji je Maretić dopuštao (usp. Maretić 1913:65), te pretežu oblici prošireni nepostojanim a: srebrnih kolajna (1923., 1: 88), crkava (1924., 2: 154, 156), u dvjema zbirkama (1924., 3: 305), Crkava (1924., 4: 399), crkvenih dobara (1928., 2: 128), u više navrataka (1928., 2: 138), zaštitnikom duhovnih vježba (1930., 3: 239), naredaba, crkvenih služba (1933., 1-2: 71), sveučilištaraka (1936., 3-4: 251), društava (1936., 3-4: 251), radi navale posala (1939., 5-6: 467), svjedodžaba (1940., 3-4: 320), bilježaka (1940., 3-4: 343), za razliku od oporbenih splitskih dnevnika koji obiluju primjerima s nastavkom -i (usp. Milinović 2014:151). Pri mogućim trojnim likovima, npr. crkava, crkva, crkvi, današnja norma također daje prednost onima s nepostojanim $a$ (usp. Težak-Babić 1992:95).

Od hrvatskih posebnosti u Novoj se reviji njeguje i sklonidba brojeva $d v a$, tri i četiri, što u biranome standardnome jeziku propisuje i suvremena norma, dok je maretićevska norma u prijedložnim svezama davala prednost nesklonjenim oblicima (usp. Maretić 1913:76). Primjeri iz uporabne norme: svih triju redova (1922., 1: 94), pali u ruke triju nesposobnih tobože neodgovornih luđaka (1924., 2: 122), na trima tablicama (1929., 1: 18), u objema pjesmama, dvaju pjesamā (sic!) (1929., 1: 24), dvaju glasova (1932., 1: 3), dvaju ideologija (sic!) (1933., 1-2: 77), u trima njegovim carstvima (1939., 5-6: 469), 
od ostalih četiriju mjesta (1941., 5-6: 49), od ovih triju čakavskih govora (1941., 5-6: 65).

U tvorbi riječi od hrvatskih posebnosti zamijećena je redovita uporaba imenica s dometkom -ba: pri izradbi (1924., 2: 191), izradbe (1924., 2: 201), obradba (1938., 3: 234), uredba (1939., 5-6: 467), te s dometkom -aj: odisaj (1924., 2: 126), uzdisaj (1924., 2: 128), napadaji (1924., 2: 191), nasrtaju (1924., 2: 159), odnošaj (1929., 1: 5), napadaja, odnošaje (1938., 3: 213). Zabilježene su i tvorenice s predmetkom vele- iako je Maretić takve tvorenice proskribirao (usp. Maretić 1899:698): Crkva velevlast mira (1922., 4: 372), veleučeni profesor (1930., 3: 228), veleumnici (1941., 5-6: 21), o velebnoj pojavi (1941., 5-6: 76). Učestali su pridjevi tvoreni dometkom -nji: dosadanjim (1922., 1: 82), sa sadanjim stanjem (1930., 3: 228), dosadanja priznanja (1938., 3: 212), »svagdanjem razgovoru « (1940, 2: 175), nutarnji čini (1924., 2: 128), kršćansku nutarnju slobodu (1929., 1: 55), nutarnji spoj (1929., 1: 12), unutarnjeg života (1938., 3: 193), unutarnjemu ritmu (1938., 3: 220-221), potom dometkom -ni: porezni zakoni (1924., 2: 121), magnetična igla (1922., 1: 7), fizična njega, fizični život, fizični odgoj (1922., 1: 8), fizično uzdržavanje (1922., 1: 9), periodičnoj štampi (1923., 1: 4), tjelesne vježbe (1924., 2: 172), fizični zakoni (1930., 1: 5). Većina je takvih tvorbenih osobitosti izraženije zamijećena i u splitskim oporbenim dnevnicima (usp. Milinović 2014:186-190).

Utjecaj srpskoga jezika očituje se u uporabi predmetka sa-, koji se javlja češće nakon 1929. godine u primjerima saopći (1929., 1: 37), saradnika (1930., 3: 229), u saglasnosti (1930., 3: 244). Redovit je pridjev savremen, na što je zasigurno utjecao naziv tadašnjega časopisa Društva hrvatskih književnika Savremenik, no usporedo se rabi i u hrvatskome liku suvremen. Hrvatski predmetak su-, zabilježen u prvim godištima Nove revije: suvremenog (1922., 1: 92), suradnik (1924., 1: 102), sudjelovanje (1924., 2: 124), sudjelovati (1924., 2: 154), u suglasju s (1924., 2: 163), zadržava se i nadalje: sudjelovati (1935., 1: 79), sumišljenike (1938., 3: 210), supatnicima (1938., 3: 235). U tvorbi pridjeva i glagola također su potvrđeni tvorbeni obrasci svojstveni srpskomu jeziku: akcionog (1922., 1: 1), paralizovalo (1922., 1: 6), ne reflektuje (1922., 1: 7), organizovani (1923., 1: 5), ignorisanje (1924. 2: 180), a tako tvorene riječi javljaju se češće nakon šestosiječanjske diktature: modelovanju (1929., 1: 62), okarakterišemo (1929., 1: 28), komplikuje (1929., 1: 30), teoretisanja (1929., 1: 31), simpatiše (1929., 31), ilustrovana (1930., 3: 238), diktovalo (1838., 3: 175), iskonstruiše (1938., 3: 235). Usporedo se međutim, sve vrijeme izlaženja časopisa, potvrđuju i hrvatskomu jeziku svojstvene tvorenice sa sufiksom -irati: simplificirao (1922., 1: 59), sintetiziraju se (1924., 2: 125), diktirala (1924., 2: 129), organizira (1924., 2: 153), analizirati (1924., 2: 169), definirati (1924., 2: 173), sistematizirana (1924., 2: 178), sintetizira (1929., 1: 28), kompromitirano 
(1929., 1: 46), kristalizirana (1929., 1: 59), ne kritiziram (1930., 3: 227), konstatirati (1938., 3: 213), prakticirati (1938., 3: 236). Zabilježeni su i pridjevi tvoreni srpskim predmetkom protivu-: protivuvjerske struje (1924., 2: 153), protivukršćanska struja (1924., 2: 164), protivurječja (1928., 2: 138), ali i s hrvatskim protu-: protualkoholna društva (1929., 1: 62), protuvjerski školski priručnici (1933., 3: 228). I takvi su primjeri u tvorbi riječi česti u drugim onodobnim novinama i časopisima (usp. Milinović 2014:189-190, 192), što pokazuje znatan utjecaj srpskoga jezika na tvorbenoj razini.

U tvorbi imena država zanimljivo je spomenuti naziv Nova Zelandija, koji je tada bio u uporabi, no u suvremenome hrvatskom jeziku ipak je zastario, premda ga u pravopisnom rječniku navode Babić, Finka i Moguš: ${ }^{13}$ Novu Zelandiju (1922., 2: 190). U onodobnim tiskovinama od imenice Amerika čest je etnik Američanin, koji je preporučivao hrvatski vukovac Rožić (usp. Rožić 1913:9), i ktetik amerikanski, koji je bio uobičajen u 19. stoljeću. U Novoj reviji pretežito se potvrđuje oblik Amerikanci (1924., 2: 207; 1929., 1: 61), što je nasljedovanje hrvatske tradicije, ali i Američani (1924., 2: 150; 1929., 1: 88), a lik amerikanski tek je rubno zamijećen: američka pedagogija (1924., 2: 173), američkih protestantskih crkava, američkim školama (1924., 2: 206), amerikanskom (1927., 3-4: 333).

Između oblika pokaznih, upitno-odnosnih i neodređenih zamjenica na -ov ili -av autori tekstova u Novoj reviji znatno su češće birali danas zastarjele, a u ono doba normativno još dopuštene oblike na -ov: ovakov, takov, kakov, nikakov... Takvi se oblici redovito rabe i u hrvatskim novinama i časopisima prve polovice 20. stoljeća (usp. Rišner-Mlikota 2018:263), no u splitskim dnevnicima praksa je bila upravo suprotna, prevladavali su oblici na -av (usp. Milinović 2014:191).

Od sintaktičkih osobitosti zapaža se da se uz perfekt povratnih glagola redovito zadržava zanaglasnica je tijekom svih godina izlaženja časopisa: držao se je (1922., 1: 1), Odgoj se je primao (1922., 1: 9), se je pripravljalo, u kojem se je nalazila (1929., 1: 5), O Tolstoju se je mnogo pisalo (1929., 1: 28), se je moglo (1930., 1: 5), Odrekao se je (1938., 5: 377), da se je Crkva zalagala (1940., 3: 225), Eto protiv čega se je borio. (1941., 5-6: 21), Tim se je mjera prevršila (1942., 1: 4). Takav dulji oblik perfekta povratnih glagola u splitskim dnevnim novinama postupno je izašao iz uporabe tridesetih godina jer se tada, navodi Milinović, počeo osjećati kao zastarjeli, stilski obilježen oblik (usp. Milinović 2014:158). Zadržavajući ga, Nova revija nastavlja s praksom starije hrvatske književnojezične tradicije. Time se može protumačiti i česta uporaba prezentskih oblika koji su u suvremenome hrvatskom jeziku stil-

13 Uz rječničku jedinicu Novozelanđanin navodi se objašnjenje stanovnik Nove Zelandije (usp. Babić-Finka-Moguš 1994:302). 
ski obilježeni: imadu (1922., 1: 4; 1938., 3: 160; 1940., 3-4: 321), zadade (1924., 2: 157), dade (1924., 2: 164; 1938., 3: 150), znade (1924., 2: 114; 1938., 5: 368), znademo (1939., 5-6: 469), izdadu (1940., 3-4: 319), a u Novoj reviji prevladavaju sve vrijeme njezina izlaženja.

Jedna od često isticanih razlika između hrvatske i srpske sintakse uporaba je infinitiva, svojstvena hrvatskomu jeziku, umjesto prezenta s veznikom $d a$, koji preteže u srpskom jeziku. ${ }^{14}$ Ondašnji su normativisti, i Maretić i Florschütz (usp. Florschütz 1907:255-258), dopuštali i infinitivnu dopunu i $d a+$ prezent. Prezent s veznikom da Maretić je čak dopuštao i za izricanje futura (»nešto ću da vam naznačim «; »sjutra ćemo da im javimo«) (1913:207), što hrvatskomu jeziku nikako nije svojstveno. Primjeri takve uporabe prezenta s veznikom da u Novoj reviji gotovo nisu ni zamijećeni: mi ćemo da rečemo (1922., 2: 150), ne će da znade (1924., 2: 114). Podjednako se međutim potvrđuju infinitivna dopuna i $d a+$ prezent uz nepunoznačne i modalne glagole: nitko ne može ništa da primijeni (1924., 2: 117), ne da postići (1924., 2: 122), zamoliše biskupe neka zakon, koji i sami drže nepravednim $i$ bezbožnim, nastoje iskoristiti osnivajući propisane bogoštovne udruge (1924., 2: 154), ne može dopustiti (1924., 2: 156), Te vježbe imaju se vršiti (1924., 2: 172), hoće da pobije istinitost (1932., 2: 123), želio da upozorim (1938: 3: 153), Stručnjak koji pročita raspravicu Dra Adžije, mora da žali njezina pisca, što se je usudio da je objelodani. (1938., 3: 212), Što sam htio istaknuti jest (1939., 5-6: 482), Ovdje bih još želio istaknuti (1939., 5-6: 489), Materijalizam ne može da riješi ni samo pitanje mrtve materije. (1940., 3-4: 328), Na ove upite može se odgovoriti samo niječno. (1940., 3-4: 319), Hoću da istaknem, Hoću da upozorim (1941., 1: 1).

Hrvatskomu jeziku svojstvena je i upitna preoblika s glagolom i česticom li. Na tu su osobitost upozoravali Guberina i Krstić, koji su u upravnim pitanjima prednost davali svezi je li, a u neupravnim pitanjima, uzimajući u obzir dotadašnju hrvatsku književnojezičnu tradiciju, dopuštali i svezu da li (usp. 1940:43). U Novoj se reviji podjednako potvrđuju obje mogućnosti i u upravnim i u neupravnim pitanjima, pa i u tekstu istoga autora: Da li ću se ja ustati u jutro (1922., 1: 7), Hoće li laička škola saći do ovoga zaglavka, ne znamo: mi ne silazimo, jer je nama škola upotpunjenje obiteljskog odgoja. (1922., 1: 8), Da li je ispravno stanovište, djaci su članovi države, i država ima absolu tno pravo na odgoj djece. (1922., 1: 10), Je li moguće, da ti siromašni, ubogi, bosonogi redovniče, imaš toliko djece i privrženika? (1922., 2: 99), Je li redovnik produktivni radnik? (1922., 2: 143), Je li katolička Crkva moderna? (1922.,

14 Usp.: »u Hrvatskoj izrazito preteže upotreba infinitiva (nisam smio zapjevati), u Srbiji da + prezent (nisam smeo da zapevam)« (Babić 1990: 297). O infinitivizaciji vidjeti u Katičić 1991:465-477 i Barić i sur. 1995:575-579. 
2: 161), No ovdje se pitamo, da li čovjek smije misliti i raditi sve, što mu se samo prohtije? (1924., 2: 117), Hoće li framasoni spasiti čovječanstvo? (1925., 2: 196), U ovo vrijeme postavlja se pitanje, da li je ekumenski koncil nad Papom. (1929., 1: 12), Ima li "bijele“ kuge kod nas? (1931., 1: 48), Da li je bl. Djevica Marija mogla sagriješiti? (1931., 5-6: 392), Je li moguće, da tako uzvišena, a ipak prosta knjiga potječe od prosta čovjeka? Da li je moguće, da Onaj (Krist) čiju povijest pripovijeda, samo je prosti čovjek? (1938., 3: 194), Ne znam je li zbirka udešavana po nekome jedinstvenome planu $i$ je li slijed svezaka ustaljen po nekome određenom principu. (1938., 3: 220). U tom kontekstu zanimljivo je spomenuti odgovor fra Stanka Petrova ${ }^{15}$ kritičaru njegova članka Ijekavski ili jekavski? ${ }^{16} \mathrm{u}$ kojem se osvrće ne samo na netočnosti u interpretaciji sadržaja svojega teksta nego i na način na koji je tekst prenesen. Petrov citira svojega kritičara: »Tri su stvari, koje treba uglavnom reformirati u pravopisu: da li će pravopis biti fonetički ili etimologijski, - da li će interpunkcija biti gramatička ili logička, - da li će se svagdje pisati mjesto staroga glasa jat samo je, koje bi trebalo izgovarati sad ije, a sad opet je već prema tome, kako traži dotični slog. «i kaže: »Najprije, tako gramatički i logički nezgrapnu rečenicu: streba reformirati, da li... ja za živu glavu ne bih napisao. (...) Evo što sam ja o tome rekao: Glasovi za reformu hrvatskoga pravopisa čuju se sve češće i sve jače, i do neke reforme bez sumnje će i doći. Pri tome glavno će pitanje biti - ako svi znaci ne varaju - hoće li novi hrvatski pravopis i dalje biti fonetičan ili će se vratiti etimologiji« (1940., 2: 173-174). Autoru teksta u jezičnom oblikovanju zasmetalo je upravo da li, on neupravno pitanje počinje glagolom i česticom li (hoće li), što pokazuje svjesnost jezičnoga izbora i skrb za osobitost hrvatskoga jezika na koju su upozorili Guberina i Krstić. U usporedbi s onodobnim tiskovinama, obje se hrvatske posebnosti, i infinitivna dopuna i upitna preoblika s glagolom i česticom $l i$, također potvrđuju u splitskim oporbenim dnevnicima (usp. Milinović 2014:163-165).

U redoslijedu zanaglasnica ogleda se hrvatska osobitost o smještanju zanaglasnice iza prve naglašene riječi u rečenici ${ }^{17}$ pa i tada kad se njome rastavlja atributna sintagma: zadnjih se je mjeseci (1922., 2: 97), Tri su vrela svećeničke nauke (1929., 3: 299), stožernom su temom njegova apostolata (1929., 3: 301), iz njezinog se života (1933., 1-2: 70), Čovječja je savjest (1938., 5: 299), naša se je domovina zvala (1941., 5-6: 5), goriški je profesor, krčki je biskup, zadnjih je deset godina (1941., 5-6: 23). Autori tekstova u Novoj reviji nisu nai-

15 Inicijale autora članka, F. S. Petrov, razrješuju Ivan Macut i Petar Macut (2018:305).

16 Navedeni je članak objavljen u Obzoru 30. prosinca 1939., 297, 4.

17 Usp.: »Ta je težnja u našem jeziku tako izrazita da zanaglasnice mogu rastavljati atribute i apozicije od riječi s kojima su uže povezane« (Težak-Babić 1992:246). 
me prihvatili Maretićev propis o slobodnom redu zanaglasnica u rečenici (usp. 1899:434-438), nego su se priklonili hrvatskoj književnojezičnoj tradiciji i pravilima zagrebačke filološke škole koja je u svojoj gramatici slijedio i Florschütz (usp. 1907:176).

\section{Leksik}

U Novoj reviji, kao i u ostalim tadašnjim tiskovinama, zapažaju se riječi koje su u hrvatski jezik ulazile pod utjecajem srpskoga jezika (usp. Rišner-Mlikota 2018:266). Već od prvih brojeva časopisa imenica upliv javlja se usporedo s hrvatskom riječju utjecaj, prevladava nakon 1929. godine, a potvrđen je i glagol uplivati: djelotvorno uplivalo (1938., 3: 194). Često se rabi pridjev prost u značenju jednostavan, običan: prosti materijal (1922., 1: 48), vjera prostoga puka (1929., 1: 8), prosta ideja (1929., 1: 11), najprostiji (1929., 1: 32), prosti pamfleti (1939., 5-6: 466), prosta izmišljotina (1939., 5-6: 475), od prostoga vojnika postade (1941., 2: 7), ali se potvrđuju i hrvatske inačice: $s$ jednostavnoga razloga (1938., 3: 152). Kao istovrijednica javlja se i u priložnom obliku: pa i kršćanska naprosto (1938., 3: 152), ali jednostavno jer on hoće da nemoralno živi (1929., 1: 40), a potvrđen je i glagolski oblik da se uprosti (1929., 1: 31). Usporedo se rabe utisak i dojam, shvatanje i shvaćanje, vanredan i izvanredan, obuhvatati i obuhvaćati, porediti, isporediti i usporediti. Hrvatska riječ inozemstvo češća je od srpske riječi inostranstvo, a pri navođenju cijene pretplate na naslovnici časopisa redovito piše: Za inozemstvo. Iako nisu česti, primjera radi kronološki navodimo još neke zamijećene srbizme: $n a-$ ličio (1922., 1: 8), vasionom (1922., 1: 57), proturiše (1923., 1: 5), udesni zakon (1923., 1: 6), najpodesnija (1923., 1: 14), nije polučila (1927., 3-4: 256), vasionog (1929., 1: 7), otadžbinom (1929., 1: 24), osebine (1929., 1: 59), krst u svezi podružnice crvenog krsta (1929., 1: 62), decenijama (1929., 1: 78), preduzimaju se (1929., 1: 62), podesno (1929., 1: 85), narednih (1930., 3: 231), predšasnik (1930., 3: 243), porađaju se, porodili (1938., 3: 212), sprovesti (1939., 5-6: 472), postepeno (1939., 5-6: 476), učestvovao (1940., 3-4: 316), snabdjeti (1940., 3-4: 333).

Od imena država koja su u hrvatskoj i srpskoj inačici supostojala u onodobnoj novinskoj praksi u Novoj su reviji, uglavnom tridesetih godina, česti srpski nazivi za Nizozemsku i Švicarsku, sukladno tomu i nazivi etnika i ktetika: Nizozemskoj (1922., 2: 190; 1927., 2: 216), Nizozemska (1935., 81; 1937., 2: 168; 1937., 5: 390; 1938., 1-2: 145), Nizozemce (1940., 3-4: 333), Holandiji (1929., 1: 62), Knjiga je prevedena na francuski, engleski i holandeski. (1929., 1: 111), Holandije (1935., 1: 79), Holandija (1934., 2: 193; 1934., 3-4: 317; 1936., 3-4: 252; 1936., 5-6: 356; 1938., 3: 239; 1938., 5: 411; 1938., 6: 496; 1939., 1: 96; 1939., 4: 342; 1940., 1: 95), Holandezi (1936., 3-4: 252), Holandsko Katoličku Udruženje (sic!) (1936., 3-4: 356), holandeskom jeziku (1938., 3: 235), holan- 
deski isusovci (1938., 3: 239), Švicarske (1924., 2: 206; 1935., 1: 79), Švicarska (1933., 4: 312), Švajcarsku državu, Švajcarskoj (1929., 1: 98), švajcarskih bezvjeraca (1933., 3: 228), Švajcarska (1934., 3-4: 320; 1934., 5: 401; 1934., 6: 478; 1936., 3-4: 253; 1936., 5-6: 368; 1937., 2: 168; 1938., 4: 323; 1938., 6: 498; 1939., 2: 157; 1940., 5-6: 276; 1941., 1: 80). S druge strane, zamijećeni su uglavnom samo hrvatski nazivi etnika i ktetika: Jugoslaveni (1924., 2: 169), jugoslavenske katolike (1924., 2: 167), jugoslavenski nacionalizam (1930., 3: 226), ali i jugoslovenskoj valuti (1923., 1: 88), Slavenu (1922., 1: 86), slavenskih provincija, Slavena, Jugoslavena (1922., 1: 94), Španjolci (1925., 1: 101), španjolske republike (1932., 1: 85), španjolskog kralja (1932., 1: 88), Židovi (1923., 3: 307; 1925., 2: 218), Židova (1926., 2: 187; 1927., 2: 215), židovskim (1923., 4: 398; 1927., 1: 97) te ime države Španjolska (1924., 2: 189; 1933., 4: 313; 1934., 2: 196).

Navest ćemo abecednim redoslijedom i neke primjere hrvatskih riječi koje su posebice nakon 1945. godine potiskivane iz aktivnoga leksika, a u Novoj se reviji redovito potvrđuju i upotrebljavaju kao posve obične, uvriježene riječi: brzojav, časnik, dalekozor, darovati, darovatelj, dopuštati, držati (potiskivano glagolom smatrati), glazba, glazbalo, gospodarstvo, gospodarski fakultet, izobrazba, izrijekom, izvornik, jamčiti, jamstvo, knjižnica, mjerodavan, mladež, načelo, načelno, naobrazba, naraštaj, nazočnost, novost, nutarnjost, objed, objelodaniti, obveza, obvezati se, obvezatnost, očevidan, odvjetnik, opetovati, oporba, opskrba, ovlastiti, pomnjivo, potrebit, pozorno, prigoda, prisega, prijeporan, pripraviti se, proračun, promicanje, rastava, redovito, sitnozor, skrb, stranka, sveza (u svezi s), štovanje, štovati, ${ }^{18}$ tablica, tijekom (tijekom vremena, tijekom povijesti), tjelesne vježbe, udruga, unutarnjost, uporaba, živci, živčani sustav, značaj, značajka. Nadalje, rabe se hrvatski likovi riječi vjerojatnost, vjerojatnije, vjerojatan. Hrvatska usvojenica točka češće se rabi od srpske riječi tačka. Posuđenica štampa i njezine izvedenice češće se bilježe u prvim godištima časopisa, no već dvadesetih godina prevladavaju hrvatske riječi $t i$ sak, tiskati, tiskara. U tom smislu zanimljivo je promotriti gdje se časopis tiskao, što se u većini brojeva izrijekom navodi: u Štampariji de Giulli i dr. u Dubrovniku, u Leonovoj tiskari u Splitu, u Tiskari »Kačić« u Šibeniku, od prvoga broja 1928. do prvoga broja 1941., te u Mostaru u Hrvatskoj tiskari F. P. Mostar, gdje je tiskan posljednji svezak. U parnjaku univerzitet/sveučilište hrvatska riječ i njezine izvedenice prevladavaju već dvadesetih godina: sveučilišni profesor, sa sveučilišnih katedri (1922., 1: 72), američkim sveučili-

18 Valja napomenuti da se u Novoj reviji nije pravila značenjska razlika po kojoj se štovati vezuje uz Boga, a poštovati uz čovjeka, što potvrđuju primjeri: Pojam štovanja samoga sebe (1924., 2: 173), kako hrvatski narod osobito štuje svoje slavne proake u borbi protiv bečkoga centralizma i peštanskih prohtjeva (1927., 3-4: 272), štovatelja Sabatierovih (1928., 2: 181). U jezičnim savjetima od 1990-ih upozorava se naime na tu značenjsku razliku u suvremenome jeziku uz često navođen primjer Bog se štuje, a čovjek poštuje. 
štima (1923., 3: 307), Katoličko sveučilište (1938., 3: 236), katoličkom sveučilištu (1939., 5-6: 499), sa sveučilišnim bogoslovskim fakultetom (1940., 3-4: 316). Posuđenica univerzitet, osim u tom liku, bilježi se i u liku univerza i universa: zagrebačke univerze (1924., 2: 175), na Gregorijanskoj universi u Rimu (1930., 3: 238). Imena mjeseci na naslovnici svih brojeva časopisa navode se hrvatskim nazivima. Hrvatski nazivi uglavnom prevladavaju i u člancima i vijestima, no ipak se $u$ onima objavljivanima $u$ prvoj polovici tridesetih godina češće javljaju i međunarodni nazivi mjeseci, tada, kao i danas, svojstveni srpskomu jeziku. U cjelini uzevši, iako je utjecaj srpskoga jezika u leksiku zamjetan, hrvatski leksik ipak prevladava.

Od riječi koje se danas osjećaju kao zastarjelice u Novoj se reviji upotrebljavaju u ono doba uobičajeni prilozi kadno, pače, sveđer, uprav i veznici akoprem, eda, kano. Dijelom aktivnoga leksika tada su bile i riječi uzgoj, uzgojitelj, uzgajati u značenju odgoj, odgojitelj, odgajati, koje u Novoj reviji pretežu: monopol na uzgoj i školu (1924., 2: 190), vjerski uzgoj svoje djece (1924., 2: 191), O uzgojiteljnoj snazi Sv. Pisma, ćudoredni uzgoj (1938., 3: 194), o tehničkom uzgoju (1939., 5-6: 475), Kačić kao pučki prosvjetitelj i uzgojitelj (1923., 1: 29), djelima uzgojena (1924., 2: 198), da bi se uzgajao umjetnički ukus učenika (1940., 3-4: 332). Zamijećene su i zastarjelice beriva (1924., 2: 178), štetovati: štetovao glas (1924., 2: 158), marvogojstvo (1929., 1: 62), preparandija: preparandijama (1941., 5-6: 20) te fonološki arhaizmi bogomilstvo (1923., 1: 3) i hotjela je (1924., 2: 128). Poneki dijalektizam tek je rubno zamijećen: Narodi (...) još uvijek živu u ratnoj spremi (1923., 1: 5), iđe (1924., 2: 164, 187), izvanka (1929., 1, 9), drugovačiji (1929., 1: 19), sio (sjeo) (1938., 3: 11), podrestu (1938., 3: 214).

\section{Zaključak}

$\mathrm{Na}$ temelju promotrenih slovopisnih i pravopisnih obilježja može se ustvrditi da je Nova revija pretežito slijedila Broz-Boranićevu normu uvođenjem grafema $đ$ te prihvaćanjem Brozova fonološkog pravopisa. Nedosljednosti u pojedinim pravopisnim rješenjima proizlazile su, s jedne strane, iz pravopisnih navika stečenih do tada uvriježenim morfonološkim pisanjem zagrebačke filološke škole, pa se ono još zatječe, uglavnom u prvim godištima časopisa, u neprovođenju jednačenja suglasnika. $S$ druge strane, Belićev pravopis i Pravopisno uputstvo, iako se Nova revija njima nije priklonila, nametnuli su fonetsko pisanje koje je bilo strano hrvatskoj pravopisnoj tradiciji, što se također odražavalo u tadašnjoj novinskoj praksi, pa tako i u Novoj reviji gdje se povremeno nailazi na provođenje jednačenja u suglasničkim skupinama $d c, d \check{c}, d c ́, d s, d \check{s}$ (potsjetiti, potcrtavam), na pisanje stranih vlastitih imena prema izgovoru, na sastavljeno pisanje futu- 
ra prvog i zanaglasnice (Nastaviće se, činiću) te zanijekanog prezenta glagola htjeti (neću). Kolebanja zapažena u prilagodbi posuđenica dijelom pak proizlaze iz nedovoljno jasne Broz-Boranićeve norme o (ne)bilježenju fonema $j$ između dvaju otvornika i nenavođenja pravila o sklonidbi posuđenica i stranih vlastitih imena, no ima i onih koja su nastala pod utjecajem srpskoga jezika. Hrvatska tradicija uglavnom se poštuje pri bilježenju pokrivenoga $r$ i češćem biranju ije nego e u dugim slogovima (prijevara, prije$k o r)$, ali se u povremenim ekavskim pojavnicama imenica starješina i starješinstvo očituje i utjecaj srpskoga jezika, a u dominantnim oblicima nijesam, nijesi... dubrovačke književnosti. U pisanju zareza poštuje se Broz-Boranićeva strukturna (gramatička) interpunkcija te se, također u skladu s BrozBoranićevim pravilom, na kraju naslova stavlja točka.

Promotrena gramatička obilježja upućuju na to da je Nova revija umnogome slijedila hrvatsku književnojezičnu tradiciju. Tako se u genitivu množine imenica daje prednost nastavku - $a$ i upotrebljavaju se oblici s nepostojanim $a$, brojevi dva, tri i četiri uglavnom se sklanjaju, imenica osnova potvrđuje se u ženskome, a teritorij u muškome rodu, glagoli imati, znati, dati česti su u oblicima s proširenom osnovom (imadu, znadu, dadu), dulji oblik perfekta povratnih glagola redovito se upotrebljava, očuvana je i infinitivna dopuna uz modalne i nepunoznačne glagole, a često se potvrđuje i upitna preoblika s glagolom i česticom $l i$ u upravnim i neupravnim pitanjima te red zanaglasnica $u$ rečenici svojstven hrvatskomu jeziku. Kolebanja u gramatičkoj uporabnoj normi u Novoj su reviji, kao i u drugim tadašnjim tiskovinama, zamijećena $\mathrm{u}$ (ne)umetanju nepostojanog $a \mathrm{u}$ imenica muškoga roda stranog podrijetla koje završavaju dvama suglasnicima nesvojstvenima fonološkom sustavu hrvatskoga jezika te u sklonidbenom tipu imenica muškoga roda sa suglasničkim završetkom i nultim nastavkom koje su pod utjecajem srpskoga jezika poprimale nastavak $a$ i sklanjale se po e-sklonidbi (npr. altruist - altruista). U tvorbi riječi očuvane su mnoge hrvatske osobitosti, no zamjetan je i utjecaj srpskoga jezika, osobito nakon 1929. godine u riječima tvorenima predmetcima i dometcima tipičnima za srpski jezik.

Izloženost prostora javne komunikacije srpskomu jeziku najviše se ogledala u brojnim srbizmima koji su tada prodirali u leksik. Srbizama ima i u Novoj reviji, no mnogi se javljaju tek povremeno. Češće se međutim nailazi na srpske riječi koje su u ono doba postale posve uobičajene pa su se i u Novoj reviji upotrebljavale kao istovrijednice usporedo s hrvatskim riječima. U većini je takvih usporednih parnjaka ipak češće birana hrvatska inačica. Skrb za hrvatski jezik pokazana je i time što, uzevši u cjelini, hrvatski leksik uvelike prevladava. 
Analiza je potvrdila početnu pretpostavku da se u Novoj reviji njeguju jezično-pravopisne značajke hrvatskoga jezika, ali je pokazala i to koliko je to tada bilo teško činiti. Kao ni druge onodobne tiskovine, ni Nova revija nije mogla umaknuti utjecaju srpskoga jezika koji, iako se ponajprije očituje na leksičkoj razini, nije mimoišao ni pravopisnu, gramatičku ni tvorbenu razinu, što još jednom potvrđuje opravdanost bojazni za sudbinu hrvatskoga jezika u tom razdoblju. No ipak, uza sva kolebanja, u promotrenim jezično-pravopisnim obilježjima Nova revija izrazitije njeguje hrvatske posebnosti, što ju svrstava u red onoga dijela novinstva koji je jezičnopravopisnim izborima potvrđivao hrvatsku orijentaciju. To je osobito bitno ima li se na umu brojnost čitateljstva i dugotrajnost njezina izlaženja jer je tako mogla utjecati na jezične navike svojih čitatelja, a time i pridonijeti očuvanju hrvatskoga jezika.

\section{Izvori}

Macut, Petar; Ivan Macut. 2018. Nova revija. (DVD-ROM). U knjizi Petar Grabić; Nova revija - Vjeri i nauci. Split: Franjevačka provincija Presvetog Otkupitelja - Služba Božja.

\section{Literatura}

Babić, Stjepan. 1990. Hrvatska jezikoslovna čitanka. Zagreb: Globus.

Babić, Stjepan; Božidar Finka; Milan Moguš. 1994. Hrvatski pravopis. Zagreb: Skolska knjiga.

Badurina, Lada. 2018. Hrvatski pravopisi i pravopisna norma u 20. stoljeću. Ur. Pranjković, Ivo; Marko Samardžija. Povijest hrvatskoga jezika, 5. knjiga: 20. stoljeće - proi dio. Zagreb: Croatica, 153-189.

Barić, Eugenija i sur. 1995. Hrvatska gramatika. Zagreb: Školska knjiga.

Belić, Aleksandar. 1923. Pravopis srpskohrvatskog književnog jezika. Beograd: Izdavačka knjižarnica Gece Kona.

Boranić, Dragutin. 1921. Pravopis hrvatskoga ili srpskoga jezika. Zagreb: Trošak i nakl. Kr. hrv.-slav.-dalm. zem. vlade.

Boranić, Dragutin. 1930. Pravopis hrvatskoga ili srpskoga jezika. Zagreb: Tisak i naklada »Jugoslovenske štampe« d. d.

Broz, Ivan. 1892. Hrvatski pravopis. Zagreb: Troškom i nakladom Kr. hrv.slav.-dalm. zemaljske vlade. ${ }^{2} 1893$.

Broz, Ivan; Dragutin Boranić. ${ }^{3} 1904$. Dra. Ivana Broza Hrvatski pravopis. Prir. Boranić, Dragutin. Zagreb: Trošak i nakl. Kr. hrv.-slav.-dalm. zem. vlade. ${ }^{4} 1906,{ }^{5} 1911,{ }^{6} 1915$. 
Florschütz, Josip. ${ }^{2} 1907$. Gramatika hrvatskoga jezika za ženski licej, preparandije i više pučke škole. Zagreb: Tisak i naklada Kr. hr.-slav.-dalm. zemaljske vlade.

Fra Ante Cikojević. Izabrani spisi. 2008. Prir. Glibota, Milan. Imotski: Matica hrvatska - Ogranak Imotski.

Frančić, Anđela. 2013. Pregled povijesti hrvatskoga jezika. Ur. Bičanić, Ante; Anđela Frančić; Lana Hudeček; Milica Mihaljević. Pregled povijesti, gramatike i pravopisa hrvatskoga jezika. Zagreb: Croatica, 7-126.

Guberina, Petar; Kruno Krstić. 1940. Razlike između hrvatskoga i srpskoga knjižeonog jezika. Zagreb: Matica hrvatska.

Katičić, Radoslav. 1991. Sintaksa hrvatskoga književnog jezika: nacrt za gramatiku. Zagreb: Hrvatska akademija znanosti i umjetnosti.

Macut, Ivan. 2018. Filozofske teme i filozofi u časopisu Nova revija (1922. 1941.). Crkva u svijetu, 1, 26-50.

Macut, Petar; Ivan Macut. 2018. Petar Grabić; Nova revija - Vjeri i nauci. Split: Franjevačka provincija Presvetog Otkupitelja - Služba Božja.

Maretić, Tomo. 1899. Gramatika i stilistika hrvatskoga ili srpskoga književnog jezika. Zagreb: Štampa i naklada knjižare L. Hartmana (Kugli i Deutsch).

Maretić, Tomo. 1913. Hrvatska ili srpska gramatika za srednje škole. Zagreb: Tisak i naklada knjižare L. Hartmana (Stj. Kugli).

Maretić, Tomo. 1931. Gramatika i stilistika hrvatskoga ili srpskoga književnog jezika. Zagreb: Naklada Jugoslavenskog nakladnog d. d. »Obnova«.

Milinović, Anđela. 2014. Jezik i pravopis splitskoga novinstva između dvaju svjetskih ratova. Doktorski rad. Zagreb: Filozofski fakultet.

Pravopisno uputstvo za sve osnovne, srednje i stručne škole Kraljevine S. H. S. 1929. Zagreb: Tisak i naklada St. Kugli.

Rišner, Vlasta. 2015. Jezik hrvatskih novina i časopisa u 19. stoljeću. Ur. Lisac, Josip; Ivo Pranjković; Marko Samardžija. Povijest hrvatskoga jezika, 4. knjiga: 19. stoljeće. Zagreb: Croatica, 245-299.

Rišner, Vlasta; Jadranka Mlikota. 2018. Jezik hrvatskih novina i časopisa u 20. stoljeću. Ur. Pranjković, Ivo; Marko Samardžija. Povijest hrvatskoga jezika, 5. knjiga: 20. stoljeće - proi dio. Zagreb: Croatica, 245-301.

Rožić, Vatroslav. 1913./1998. Barbarizmi u hrvatskom jeziku (pretisak). Zagreb: Pergamena.

Samardžija, Marko. 1995. Leksikologija i povijest hrvatskoga jezika u XX. stoljeću. Udžbenik za 4. razred gimnazije. Zagreb: Školska knjiga.

Samardžija, Marko. 2018. Hrvatski jezik od početka 20. stoljeća do godine 1945. Ur. Pranjković, Ivo; Marko Samardžija. Povijest hrvatskoga jezika, 5. knjiga: 20. stoljeće - proi dio, Zagreb: Croatica, 9-55. 
Težak, Stjepko; Stjepan Babić. 1992. Gramatika hrvatskoga jezika. Zagreb: Školska knjiga.

\title{
Language and Ortography of \\ Nova revija - Vjeri i nauci
}

\begin{abstract}
The Paper deals with the accepted norm of the Croatian Language in the Nova revija - Vjeri $i$ nauci had been continually published during the two for the Croatian language stormy and crucial decades for its survival, from 1922 to 1941. The aim of the research was to get a better insight into the linguistic characteristics in the New Review as for its linguistic and ortographic traits of the Croatian Language, which within that period had been highly exposed to the overwhelming influence of the Serbian.

By an analysis carried out there were included: spelling, orthography, grammer, and lexis, with special reference to those linguistic-orthographic features typical of the Croatian, and typical of its particularity. The analysis has affirmed the initial assumption that the New Review stuck to the linguistic-orthographic features of the Croatian, but also pointed out rightly to discrepancies between the Croatian linguistic-orthographic tradition, all influenced by the Serbian language.

The same as in other printed matters at the time, that influence was firstly felt at the lexical level, but coming soon to touch the orthographic, grammer, and word formation levels. However, despite all vacillation, Nova revija more distinctly cherished the Croatian peculiarity, thing that aligned it with those who had voted it in the period mentioned above as the confirmed pro-Croatian orientation.
\end{abstract}

Ključne riječi: Nova revija, jezik, pravopis, hrvatska jezično-pravopisna tradicija

Keywords: Nova revija, language, orthography, Croatian linguistic-orthographic tradition 